\title{
Factors Contributing to the Successful Implementation of Management Innovations
}

\author{
Zdravko Zekić \\ University of Rijeka, Faculty of Economics, Croatia \\ zdravko.zekic@efri.hr \\ Mirjana Grčić Fabić \\ University of Rijeka, Faculty of Economics, Croatia \\ mirjana.grcic.fabic@efri.hr \\ Luka Samaržija \\ University of Rijeka, Faculty of Economics, Croatia \\ luka.samarzija@efri.hr
}

\section{ABSTRACT}

The concept of management innovation as distinctive type of nontechnological innovations is still in the early days of conceptual formation and confirmation. This paper aims to investigate the concept of management innovations in public sector organizations with an emphasis on identifying the impact of organizational factors on the successful implementation of management innovations. The aim of implementation of new management concepts and methods is to increase efficiency and effectiveness of public services. A research was conducted on a sample of local self-government units in Croatia using empirical methods. The obtained results confirm the set conceptual determinants of the management innovation term, as manifested through the influence of selected organizational factors. Accordingly, absorptive capacity and top management support, with the combined effects of implementation climate and innovation-values fit, have been identified as key factors to achieving successful implementation of management innovations. On the other hand, availability of significant financial resources was not found to be a significant factor for the effective implementation of this type of innovation. Research results suggest theoretical and practical implications for strengthening the effectiveness of local self-government.

Key words: management innovation, non-technological innovation, innovation implementation, local self-government, effectiveness.

JEL: H83, H76 


\section{Introduction}

Evaluating management innovations is a concept still in the early stages of development and is one that has still not received sufficient scholarly attention. Unlike technological innovation, which is concerned with changes in technology related to the organization's core business processes, management innovations break into social spheres and their focus is on people - managers. Management innovations can be defined as the process of creating and implementing new practices, processes, structures or techniques in management which may significantly deviate from existing practices and standards (Birkinshaw, Hamel, Mol, 2008). Management innovations defined as non-technological types of innovation break into social spheres of the organization, which means that this innovation is intangible, abstract and complex, and implies a long-term impact on organizational performance.

The authors became interested in conducting research on this type of innovation because it has been given insufficient scientific attention. This particularly applies to public sector. A common practice nowadays is that organizations, especially those in public sector that are more exposed to institutional pressure, tend to implement change and innovation that has already proven successful. A shortage of innovation, in other words, its slow dynamics across such organizations comes from structural inertia as a constraint on the organization's ability to change. In conclusion, therefore, it can be seen that the majority of public sector innovation has been copied and pasted from the outside. Innovation is adoption, assimilation and exploitation of a novelty to the benefit of the organization. This implies that innovation can be viewed as a process that takes place in several steps influenced by a number of different factors aimed at achieving a value-added target.

The existing studies in the field of management innovations mostly evaluate the influence of management innovations on organisational outcomes, not taking into account those factors that promote the creation and implementation of such innovations. It can therefore be concluded that most research on management innovations has focused on the effects of innovations while less focused on the process of innovation implementation itself. This paper develops and tests a conceptual model of factors that contribute to the successful implementation of management innovations in public sector organizations, ie. local self-government units in Croatia, enabling analysis of management innovations both from the viewpoint of the implementation process itself and the expected effects of innovations.

Like other countries, Croatian public administration system has been marked by recently commenced organizational and managerial reforms aimed at improving the effectiveness and efficiency of organizational processes and public activities. It is expected that such demands will affect the introduction and implementation of management innovations in the selected cities and municipalities. In addition, the research has been tailored to the context of 
local self-government because of specificities of local government as the lowest level of public administration, which also makes their advantages, or, in other words, their fundamental function. This implies the ability of local self-government to provide local public goods in accordance with local preferences, and in a more cost-effective manner than the higher level of public administration. This leads to a more flexible and creative approach to providing public services, which requires innovative solutions and strategies to adequately respond to changes in the local environment, as opposed to services provided at the highest levels of public administration. In this context, the paper examines the impact of organizational factors that contribute to the successful implementation of management innovations and the effect of management innovations on improving the effectiveness of local selfgovernment in Croatia.

\section{Theoretical Background}

Few researches have addressed the issue of management innovations. Previous work has mostly focused on technological innovations in the private sector (Orlikowski, 1993, Mehrtens, Cragg and Mills, 2001, Suchan, 2001, Klein, Conn and Sorra, 2001, Jones and Kochtanek, 2004, Letaifa and Perrien, 2007, Jensen and Aanestad, 2007, Bryson et al., 2008), while nontechnological innovations are still poorly understood (Kennedy, Kelleher and Quigley, 2006, Braunscheidel et al., 2011). The issue of non-technological innovations has not been dealt with in depth (Lorsuwannarat, 2013, van der Voet, 2013, Weiner, Lewis, Linnan, 2009, Choi and Chang, 2009), especially in the field of public sector.

Lorsuwannarat (2013) came to the conclusion that knowledge management and collaborative network strategies are key factors to the successful implementation of management innovations. In his work, he focuses on discontinuity in the implementation of innovation in the public sector. It is generally accepted that it is a combination of management innovations and knowledge management practices that leads to a lower discontinuity rate drawing a parallel with organizations that do not use knowledge management. Collaborative networks can serve as a factor that may contribute to an increase in innovative activity. In other words, an organisation can use external sources of knowledge in creating and implementing innovations thereby reducing complexity in using an innovation, especially with regard to uncertain and conflicting inputs, processes and outputs.

Voet (2013) lists factors that contribute to the effective implementation of organizational changes in the public sector. He examines the role of transformational leadership in different approaches to change management process: planned and unplanned change process and the impact of bureaucratic structures on the implementation of organizational changes. In his survey carried out on a sample of public organizations in Denmark, the 
author reached the conclusion that bureaucratic organizations can effectively implement organizational changes, both in planned and unplanned change processes. In a non-bureaucratic context, the significance of transformational leadership is not so pronounced in the planned change process as it is in the unplanned change process.

In their analysis, Weiner, Lewis and Linnan (2009) developed a theoretical framework of organizational determinants of effective implementation of complex health promotion programs at work. The model is based on theoretical and empirical evidence for implementation of complex innovations in production, education and healthcare and largely relies on the model developed by Klein et al. (2001). The authors underline the following factors that contribute to the effective implementation of management innovations: organizational readiness for change, implementation policies and practices, implementation climate and innovation-values fit. However, the model must be tested empirically to validate the significance of the afore mentioned variables for effective innovation implementation.

Choi and Chang (2009) explained innovation implementation on a sample of public agencies and ministries through organizational and institutional factors such as top management support, resource availability (financial, human and social, for example support for the best innovators, spread of innovations for social networks etc.), and learning support, including individual factors, in other words, collective innovation acceptance processes. A positive correlation between the institutional factors and effective innovation implementation has been demonstrated. However, the top management support factor has been proved to be the only predictor variable that can significantly affect innovation implementation effectiveness. This is in line with previous research conducted in the private sector suggesting that employees tend to get a positive attitude about innovation implementation when institutional elites or managers express their support for innovation and provide a clear vision and strategy for its implementation (Klein et al., 2001, Purvis et al., 2001, Russel, Hoag, 2004).

In defining determinants of innovation implementation effectiveness, Helfrich et al. (2007) relied on a model of innovation implementation effectiveness validated in the context of a private manufacturing setting (Klein et al., 2001). The authors proposed the following relationships among variables: effective innovation implementation is the function of top management support and financial resource adequacy, the impact of which is achieved through mediating effects of individual organizational implementation policies and practices, and the resulting implementation climate. Furthermore, the authors claim that additional variables such as leading innovations and innovationvalues fit contribute to implementation climate. This theoretical framework has been empirically supported by a few national research centres. 
Klein et al. (2001) developed a model that was the first to integrate the known innovation implementation factors into general factors that could be applied to all types of innovation, and that was tested through procedures of quantitative empirical research, unlike previous predominantly qualitative case-study approach. Most previous evidence measured implementation of specific type of innovation, such as process innovation or product innovation, and outlined several factors of their successful implementation. It was mostly about integrative models grounded on case-based research. The model built by Klein et al. was distinguished from other models by the fact that it was designed to integrate the theory of innovation implementation by defining general factors that could contribute to the successful innovation implementation in most organizations, which had been defined and tested empirically in previous research as individual factors.

The model was tested in a manufacturing setting on a sample of enterprises that had implemented manufacturing resource planning method. By verifying the model in the private sector, the authors were able to validate the appropriateness of the factors and the whole model (Sawang, 2008, Holahan et al., 2004, Pullig et al. 2002). Few researches have addressed the issue of application of the model in the public sector (Weiner, Lewis, 2009, Helfrich et al., 2007). The factors represent organizational features that together contribute to increase the likelihood of success in innovation implementation: top management support, financial resource adequacy, implementation policies and practices, and a strong and positive implementation climate. This paper adapts the model (Klein et al., 2001) to assess management innovation implementation in the public sector. Unlike original research that addressed process innovation, this paper explores management innovations as a set of innovations that share common features.

\subsection{Factors Contributing to the Successful Implementation of Management Innovations to Improve the Effectiveness of Local Self-government}

Management innovations аге new management practices, processes, techniques or structures that require a considerable number of interdependencies among organizational units and members. Unlike other types of innovation, management innovations involve comprehensive changes in practices, processes or structures within an organization and affect the way management works and how people work with each other. This implies the key role of social aspects of management innovations through organizational culture, employees' attitudes and subjective norms, and hierarchy of authority. Likewise, the intangible nature of management innovations makes it difficult to measure their effects and evaluate how an organisation perceives efficiencies gained by an innovation. This implies a comprehensive and complex type of innovation, which involves systematic application and coordination of many organizational members. 
This paper uses the proposed conceptual model to investigate management innovation implementation considering factors that can influence successful implementation of this type of innovation such as: financial resource adequacy, top management support, absorptive capacity, implementation climate and innovation-values fit. Unlike the original model, the paper introduces additional variables such as absorptive capacity and innovation-values fit to emphasize the nature of management innovations and their impact on organizational culture and interpersonal relationships, the importance of learning process, linking and collaboration to assimilate management innovations into local self-government. Scheme 1 shows the conceptual model of factors that contribute to the effective implementation of management innovations.

Scheme 1. Conceptual model of factors contributing to the effective implementation of management innovations

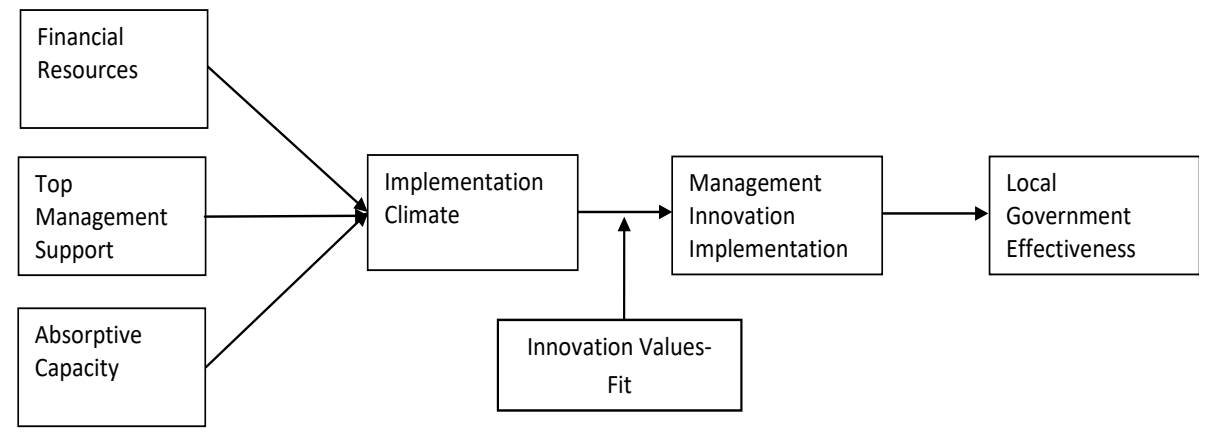

In their model of efficient implementation, Klein etal. (2001) assumed a positive correlation between financial resources and innovation implementation efficiency. Unlike technological innovations, which usually require special research and development, expertise and significant financial resources, management innovations defined as non-technological types of innovation do not generally involve expertise and infrastructure. This implies that creating and implementing management innovations does not necessarily demand large financial resources (Birkinshaw, Hamel, Mol, 2008). Certainly, more financial resources are likely to facilitate access to adequate education. A positive correlation between financial resources and implementation climate has therefore been assumed, but their effect on top management support and absorptive capacity is expected to be less pronounced. Thus, the following hypothesis is proposed:

H1: Financial Resources have a positive impact on an organisation's climate for implementation of management innovations.

Klein et al. (2001) defined the implementation climate construct based on previous conceptual and empirical evidence on implementation climate. Implementation climate implies a high degree of within-organization agreement in climate perceptions. In other words, the extent to which organizational policies and practices encourage and support innovation 
implementation. Depending on how new management methods and practices are assimilated into the existing organizational context, so the importance of innovation implemented by the organisation will be perceived. Damanpour and Schneider (2006) relied on the existing review of the literature on the topic of strategic leadership and found out that top management can contribute to organizational performance by shaping organizational culture, influencing organizational climate, and building capacity for change and innovation. Accordingly, the following hypothesis is proposed to examine the relationship between top management support and implementation climate in local self-government:

H2: Top management support has a positive impact on an organisation's climate for implementation of management innovations.

Cohen and Levinthal (1989) described absorptive capacity as the ability to identify, assimilate and exploit knowledge of the environment or organizational learning or absorptive capacity. Since innovation is no longer seen as a purely technical process, but as a knowledge intensive activity, which requires managerial and technical abilities, as well as external linking for cooperation, networking and information acquiring (Koch, Strotmann, 2008), the absorptive capacity concept has been predominantly used in innovation research. A number of studies have addressed the effect of absorptive capacity both in development of technological innovations (Tsai, 2001, Stock et al., 2001) and non-technological innovations, such as business model innovation (Gebauer et al., 2011). Absorptive capacity enables organizations to adapt their own organizational processes to incorporate new ideas and knowledge into existing structures and processes. Likewise, the newly acquired knowledge must be integrated with existing organizational features.

This paper discusses absorptive capacity as organizational capacity for adaptation, introduction and implementation of innovations. In a major advance in 2011, Kostopoulos et al. (2011) showed that those organisations which cooperate with various external stakeholders tend to increase their knowledge base and improve ability to assimilate and exploit the so acquired knowledge. This is very important for public sector organizations, and especially for local self-government. In the public sector, the key source of information and knowledge is the constant interactivity with stakeholders. So as technological innovations are primarily developed within the boundaries of an organization, so management innovations emerge or become adopted through interaction with the environment (Birkinshaw, Mol, 2006). This is particularly important for public sector organizations, where innovation processes imply adopting existing, proven management methods and practices as opposed to exploratory innovations. Thus, it is seems appropriate to explore the absorptive capacity construct in the context of implementation of management innovations through its effects on implementation climate. Accordingly, the following hypothesis is proposed to examine the relationship between absorptive capacity and implementation climate: 
H3: Absorptive capacity has a positive impact on an organisation's climate for implementation of management innovations.

Klein et al. (2001) claimed a positive correlation between implementation climate and efficient implementation for process innovation. Relationships between management innovations and implementation climate have not been dealt with in depth. Current solutions regarding relationships between management innovations and implementation climate appear to be grounded on existing evidence on implementation of other types of innovation. Apart from Klein et al. (2001), also Sawang (2008) claims that there is a positive relationship between the two constructs. She described innovation implementation as a collective construct composed of production, process and management innovations. In their work, Klein and Sorra (1996) argued that efficient implementation was a function of an organization's climate for the implementation of a given innovation and collective perceptions on how proposed values fitted with the existing organisational values. As the relationship between implementation climate and management innovation implementation can be viewed as a function of organisational members' perceptions of the fit of the innovations to their values, this paper suggests a moderating effect of the innovation-values fit construct on the relationship between implementation climate and management innovation implementation, or, in other words, the moderator increases or decreases the strength of correlation between the two variables. Accordingly, the following hypotheses are proposed:

H4: Implementation climate has a positive impact on management innovation implementation.

H5: Innovation-values fit has a moderating effect on the relationship between implementation climate and management innovation implementation.

Management innovations defined as non-technological types of innovation bring changes of intangible nature that depend on the context of the implementation effort. For these reasons, it can be difficult to empirically test the effects of implementing management innovations on organizational performance. In general, it can be concluded that establishing a strong empirical link between innovation and performance is difficult due to some methodological defects such as construct measurement as well as technological and market circumstances, which makes the impact of innovation unpredictable (Tidd, 2001). In the literature there are many examples of the importance of management innovations for organizational performance. However, further empirical assessment of this issue is necessary. This is particularly true of empirical testing in public sector organizations. A recent review of the literature on this topic found that management innovations have a positive impact on dynamic abilities (Gebauer, 2011), productivity growth (Mol, Birkinshaw, 2009) and organizational performance (Černe, 2013, Camisón, Villar-López, 2012, Walker etal., 2011, Gunday et al., 2011, Sapprasert, 
2008, Yeh-Yun Lin, Yi-Ching Chen, 2007, Gera, Gu, 2004). Hard performance measures typically used to measure outcomes of management innovations are profitability, productivity, growth and sustainable, competitive advantage (Volberda et al., 2013). Also, management innovations can contribute to satisfying soft goals (Birkinshaw et al., 2008) such as reducing employee turnover (Hamel, 2011, Kossek, 1987), improving customer satisfaction (Linderman et al., 2004) as well as motivating and improving satisfaction of other stakeholders such as employees (Mele, Colurcio, 2006).

It has not yet been established the extent to which management innovations affect performance in public organizations. Walker et al. (2011) highlighted the impact of management innovations on organizational performance in local self-government in the UK. The first indicator of performance was the core services performance score from the Comprehensive Performance Assessment conducted by the Audit Commission. The study confirmed the existence of an indirect, positive influence of management innovations on organizational performance through performance management systems: output quantity and quality, efficiency, customer equity and customer satisfaction. On the other hand, it showed negative direct effect. The authors suggested that the negative effect could have been explained by a lack of studies conducted within a one year time frame. The study did not go deeper into exploring factors that contribute to efficient innovation implementation and the characteristics of the process of creating and implementing innovations. Accordingly, the following hypothesis is proposed:

H6: Management innovation implementation has a positive effect on local self-government performance.

\section{Methodology}

Hierarchical regression was used to prove Hypotheses $\mathrm{H} 1, \mathrm{H} 2, \mathrm{H} 3, \mathrm{H} 4$ and $\mathrm{H} 5$. All analyses involved the influence of the size of local self-government unit as a control variable, given the previous evidence that also included this control variable, to consider alternative explanations. Logistic regression will be used to test Hypothesis H6. Logistic regression is suitable for use when a dependent variable is expressed as binary or when it is a categorical variable, which can be either ordinal or nominal, that is, structured or unstructured.

Hierarchical regression is often used when data is organized in a hierarchical structure to determine and emphasize the contribution of an individual variable or set of variables to the model. In this way, direct comparison of distinct predictive strength values is enabled (Vaccaro et al., 2012, Rodwell, Noblet, Allisey, 2011, Vigoda-Gadot, Meiri, 2008, Noblet, Rodwell, McWilliams, 2006). For example, Vaccaro et al. (2012) in their paper on management innovation and leadership also use hierarchical regression to evaluate the influence of an individual variable and of set of variables in transformational and transactional leadership, as well as the role of control and moderating variables in realizing 
management innovations. In their study on demand-control-support model in the work environment of public sector organizations, Rodwell et al. (2011) also use hierarchical regression to determine the contribution of specific predictors of occupational strain. In addition to hierarchical regression, this paper used logistic regression to test the last hypothesis (H6). Logistic regression is suitable for use when the dependent variable is expressed as a binary or categorical variable. In the conducted survey, effectiveness of local self-government units is expressed in three measures, one of which is numerical (budget value / employee expenses) and the other two categorical. For this reason and to achieve greater precision, logistic regression was used in assessing significance of regression coefficients of the impact of implementation of management innovations on the effectiveness of local self-government units.

\subsection{Sample}

An empirical survey was conducted among Croatia's local self-government units during 2014. There is currently a total of 128 cities and 428 municipalities in Croatia, making up a total of 556 local self-government units. The main criterion in selecting sampling units was the required minimum population of 3000, making up a total of 282 local self-government units. One of the aims of criterion referencing was to explore management innovations in a comprehensive manner, considering that large-sized local self-government units are assumed to implement management innovations at higher levels. Questionnaires were sent via electronic mail and received a 25\% response rate, making up a total of 71 local self-government units. The questionnaire was intended for top management. The questionnaire was sent to officials heading administrative departments or similar organizational departments as they are best-acquainted with the subject matter cited in the questionnaire. It mostly involved Head of Department of Local Self-Government and Administration, depending on the specific organization of the local self-government unit. They were also contacted by telephone to be additionally informed about the survey and to obtain a confirmation of their participation. However, since this does not ensure that top management really participated in the survey, during analysing and interpreting data the mentioned limitation has to be taken into account. Since the main subject of this research is innovations which are generally positively connoted, the phenomenon of social desirability can be expected to occur. It is possible that the target respondents in the survey tended to present a favourable image of their local government unit or themselves in order to conform to socially acceptable values and gain social approval. In order to reduce the risk of socially desirable responses, we conducted an online administered survey questionnaire. The Internet survey mode has been shown to reduce social desirability response bias due to selfadministration (Holbrook/Krosnick 2010). Moreover, questions were specific and presented in a neutral fashion, based on facts and leaving little room for 
broader thinking and expression of attitudes. Therefore, the authors believe that this has reduced the number of social desirable responses.

Besides collecting data through questionnaire, data was collected from official financial statements to reduce survey bias. The study was based on a 1-factor solution to avoid common method bias. The extracted factor attained a specific value of 18,925 and the total explained variance contribution rate has reached $37.107 \%$. The explained variance lower than $50 \%$ means common method bias was not present.

\subsection{Measurement of Variables}

The characteristics of management innovations have not been dealt with in depth, especially in the field of local self-government. To establish latent relationships among measured items a factor analysis was used with mainly original variable importance measures. Cronbach's alpha measure was used to assess the reliability. The results confirmed internal consistency and construct validity of measured variables.

\subsubsection{Financial Resources}

The share of own-source revenues in the total budget as an indicator of local financial autonomy may be viewed as an approximate measure of the adequacy of local financial resources to support innovation activities. In Croatia, ownsource revenues account for no more than $5 \%$ of the total budget revenues. Most of own-source revenues are used for regulatory purposes only, which is basically considered a disadvantage in the design of fiscal autonomy. In other words, it may be difficult to find an appropriate indicator of the adequacy of financial resources for these purposes. An additional problem is that it may prove difficult to find comparable data on types of revenue in financial statements or budget statements. These were the reasons for choosing budget value as being an approximate measure of financial strength, and then as an implicit measure of local strengths in supporting innovation implementation activities. The budget value refers to 2012 .

\subsubsection{Top Management Support}

The top management support construct involved three assertions evaluated by the Likert scale. Table 1 is a list of assertions related to top management support to which respondents agreed or disagreed on a five-point scale (from $1=$ I totally disagree to $5=$ I completely agree). A rate of agreement with each assertion was obtained (mean value and standard deviation). 
Table 1. List of assertions related to top management support with descriptive statistics

\begin{tabular}{|l|l|l|}
\hline Assertions & $\begin{array}{l}\text { Mean } \\
\text { value }\end{array}$ & $\begin{array}{l}\text { Standard } \\
\text { deviation }\end{array}$ \\
\hline $\begin{array}{l}\text { Mayor and Department Heads set examples for others, and } \\
\text { encourage creative approaches in solving problems and carrying } \\
\text { out services. }\end{array}$ & 3.69 & 1.01 \\
\hline $\begin{array}{l}\text { Mayor and Department Heads set examples for others, and } \\
\text { encourage proactive approach on how to innovate organization of } \\
\text { work. }\end{array}$ & 3.59 & 1.10 \\
\hline $\begin{array}{l}\text { Your unit of local self-government has adopted measures for } \\
\text { rewarding innovative approaches to organizing work, solving } \\
\text { problems, and generally proposing new projects and programs. }\end{array}$ & 2.32 & 1.20 \\
\hline
\end{tabular}

Innovation support commitment by top management is reflected primarily in Mayor/Department Heads' desire to set examples for others and encourage creative approaches in solving problems. A 1-factor solution analysis was used to make an evaluative assertion analysis of the top management support construct. The extracted factor attained a specific value of 2.257 (KMO =0.566, Bartlett $=128.392, p<0.001)$ and the total explained variance contribution rate has reached $75.240 \%$. Cronbach's alpha estimate of reliability showed a coefficient of 0.822 .

\subsubsection{Absorptive Capacity}

Table 2 is a list of assertions related to absorptive capacity. A rate of agreement with each assertion was obtained (mean value and standard deviation).

Table 2. List of assertions related to absorptive capacity with descriptive statistics

\begin{tabular}{|l|l|l|}
\hline Assertions & $\begin{array}{l}\text { Mean } \\
\text { value }\end{array}$ & $\begin{array}{l}\text { Standard } \\
\text { deviation }\end{array}$ \\
\hline $\begin{array}{l}\text { Budget includes funds for professional development training } \\
\text { and education (various seminars, courses, professional journal } \\
\text { subscriptions). }\end{array}$ & 1.98 & 0.12 \\
\hline $\begin{array}{l}\text { Meetings with stakeholders from the environment such as } \\
\text { entrepreneurs, associations, citizens or investors (Local Action } \\
\text { Groups) are organised on a regular basis. }\end{array}$ & 3.88 & 1.06 \\
\hline $\begin{array}{l}\text { Your unit of local self-government consults and shares experience } \\
\text { about best practices in solving specific issues with other units of } \\
\text { local self-government. }\end{array}$ & 3.70 & 1.02 \\
\hline $\begin{array}{l}\text { Your unit of local self-government works in partnership and creates } \\
\text { networks with other units of local self-government, counties, } \\
\text { economic entities or local and foreign institutions aimed at creating } \\
\text { and implementing development programs and projects as part of } \\
\text { the strategy. }\end{array}$ & 3.25 & 1.07 \\
\hline $\begin{array}{l}\text { Regular scheduled meetings between Mayor and Department Heads } \\
\text { are held as part of the routine at work, for example on a weekly } \\
\text { basis. }\end{array}$ & 3.68 & 1.52 \\
\hline
\end{tabular}




\begin{tabular}{|l|l|l|}
\hline Assertions & $\begin{array}{l}\text { Mean } \\
\text { value }\end{array}$ & $\begin{array}{l}\text { Standard } \\
\text { deviation }\end{array}$ \\
\hline $\begin{array}{l}\text { A continuous information system within the organization has been } \\
\text { established on new legal regulations, external information of } \\
\text { interest and similar information (intranet). }\end{array}$ & 3.35 & 1.29 \\
\hline $\begin{array}{l}\text { Educational workshops and training for introduction and } \\
\text { implementation of changes and innovations involving the } \\
\text { organization are organised regularly. }\end{array}$ & 2.88 & 1.19 \\
\hline $\begin{array}{l}\text { Departments share knowledge and experience at meetings or in } \\
\text { some other commonly agreed manner. }\end{array}$ & 3.56 & 1.17 \\
\hline $\begin{array}{l}\text { Employees apply new acquired knowledge (from legal regulation, } \\
\text { seminars, courses etc.) in their work. }\end{array}$ & 3.98 & 0.81 \\
\hline $\begin{array}{l}\text { Employees often suggest improvements, present ideas for } \\
\text { innovative programs and projects. }\end{array}$ & 3.28 & 1.01 \\
\hline
\end{tabular}

The surveyed cities and municipalities have been largely building absorptive capacity, described as the ability to identify, assimilate and exploit knowledge of the environment - or organizational learning capability, by holding regular meetings with stakeholders such as entrepreneurs, associations, citizens or investors (Local Action Groups), consulting and sharing experience with other units of local self-government about best practices in solving specific issues and providing opportunities to employees to be able to apply the knowledge acquired from legal regulation, seminars, courses, etc. A 1-factor analysis was used to make an evaluative assertion analysis of the absorptive capacity construct. The extracted factor attained a specific value of $4.890(\mathrm{KMO}=0.823$, Bartlett $=311.794, p<0.001)$ and the total explained variance contribution rate has reached $54.332 \%$. Cronbach's alpha estimate of reliability showed a coefficient of 0.890 .

\subsubsection{Implementation Climate}

The implementation climate construct involved six assertions, tailored to the organizational context of a local self-government unit corresponding to feedback from top managers. Researchers who addressed the issue of implementation climate suggested that assertions designed to measure the implementation climate construct should be descriptive rather than evaluative. This means that an opinion should be given as to whether relative objective and neutral descriptions of the working environment are correct or incorrect (Weiner et al., 2011). Table 3 is a list of assertions related to implementation climate. A rate of agreement with each assertion was obtained (mean value and standard deviation). 
Table 3. List of assertions related to implementation climate with descriptive statistics

\begin{tabular}{|l|l|l|}
\hline Assertions & $\begin{array}{l}\text { Mean } \\
\text { value }\end{array}$ & $\begin{array}{l}\text { Standard } \\
\text { deviation }\end{array}$ \\
\hline $\begin{array}{l}\text { Employees receive educational support when work organization is } \\
\text { changed. }\end{array}$ & 3.33 & 1.18 \\
\hline $\begin{array}{l}\text { Employees receive recognition for successful application of new } \\
\text { methods of work. }\end{array}$ & 2.78 & 1.08 \\
\hline $\begin{array}{l}\text { Management receives recognition for successful application of } \\
\text { new methods of work. }\end{array}$ & 2.52 & 1.10 \\
\hline $\begin{array}{l}\text { Employees are regularly informed at meetings about innovative } \\
\text { approaches and methods of work. }\end{array}$ & 3.04 & 1.19 \\
\hline $\begin{array}{l}\text { Management's point of view is that it is very important to } \\
\text { encourage employees to further educate themselves regarding } \\
\text { new work methods enabling them to apply innovative approaches } \\
\text { in their work. }\end{array}$ & 3.19 & 1.21 \\
\hline $\begin{array}{l}\text { Management staff and their close assistants use words such } \\
\text { as change, innovation, importance of innovative approaches in } \\
\text { organization or teamwork. }\end{array}$ & 3.24 & 1.27 \\
\hline
\end{tabular}

Implementation of new management methods and practices in local selfgovernment has been mostly perceived as an effort to support and give organisational members opportunities to accept and apply new methods of work. The extracted factor attained a specific value of 3.972 ( $\mathrm{KMO}=0.826$, Bartlett $=238.439, \mathrm{p}<0.001)$ and the total explained variance contribution rate has reached $66.200 \%$. Cronbach's alpha estimate of reliability showed a coefficient of 0.893 .

\subsubsection{Innovation-Values Fit}

The following assertions have been defined based on the theoretical construct and previous empirical evidence to examine the alignment between values created through management innovations and the organisation's values. Table 4 is a list of assertions related to innovation-values fit. A rate of agreement with each assertion was obtained (mean value and standard deviation).

Table 4. List of assertions related to innovation-values fit with descriptive statistics

\begin{tabular}{|l|l|l|}
\hline Assertions & $\begin{array}{l}\text { Mean } \\
\text { value }\end{array}$ & $\begin{array}{l}\text { Standard } \\
\text { deviation }\end{array}$ \\
\hline $\begin{array}{l}\text { I believe that implementation of innovative approaches and } \\
\text { methods in organization and management such as teamwork, } \\
\text { project management, quality management etc. is important in } \\
\text { achieving goals and strategic objectives. }\end{array}$ & 4.31 & 0.76 \\
\hline $\begin{array}{l}\text { I believe that implementation of innovative approaches and } \\
\text { methods in organization and management in our unit of local } \\
\text { self-government can significantly contribute to improving its cost } \\
\text { efficiency. }\end{array}$ & 4.30 & 0.78 \\
\hline
\end{tabular}




\begin{tabular}{|l|l|l|}
\hline Assertions & $\begin{array}{l}\text { Mean } \\
\text { value }\end{array}$ & $\begin{array}{l}\text { Standard } \\
\text { deviation }\end{array}$ \\
\hline $\begin{array}{l}\text { I believe that implementation of innovative approaches and } \\
\text { methods in organization and management in our unit of local self- } \\
\text { government can ultimately result in higher quality of our services, } \\
\text { and increase user satisfaction. }\end{array}$ & 4.29 & 0.70 \\
\hline $\begin{array}{l}\text { I believe that systematic implementation of innovative approaches } \\
\text { and methods in organization and management in our unit of } \\
\text { local self-government can significantly contribute to my further } \\
\text { professional development. }\end{array}$ & 4.38 & 0.79 \\
\hline
\end{tabular}

Alignment between values created through management innovations and the organisation's values has been mostly perceived as systematic implementation of management innovations that can significantly contribute to further professional development of organisational members. The extracted factor attained a specific value of 3.384 ( KMO $=0.814$, Bartlett $=251.164, p<0.001)$ and the total explained variance contribution rate has reached $84.603 \%$. Cronbach's alpha estimate of reliability showed a coefficient of 0.937 .

\subsubsection{Implementation of Management Innovations}

Previous work has been limited to tangible innovation such as technological. The field of measuring management innovations and their effects is a methodologically challenging area due to complexity and diversity of management innovations. The concept of management innovations is still poorly understood and there is insufficient empirical evidence to validate the concept. Studies conducted on the issue of measurement of management innovations have provided a few empirical measures for construct measurement (Černe, 2013, Vaccaro et al., 2012, Gunday et al., 2011, Mol, Birkinshaw, 2009, Walker et al., 2011, Walker, 2006).

The following assertions have been defined based on the theoretical background and previous empirical evidence on measurement of management innovation tailored to the context of local self-government in Croatia. Before drafting the final questionnaire, the final assertion statements were composed in such a way as to incorporate suggestions from local self-government staff holding managerial positions. Table 5 is a list of assertions related to implementation of management innovations to which respondents agreed or disagreed on a five-point Likert scale to assess management innovation implementation in the respondent's local self-government unit ( $1=$ Not implemented, 2 = Implemented in a few segments, 3 = Partly implemented, 4 = Almost fully implemented and 5 = Fully implemented). The survey period was 5 years. A rate of agreement with each assertion was obtained (mean value and standard deviation). 
Table 5. List of assertions related to implementation of management innovations with descriptive statistics

\begin{tabular}{|c|c|c|}
\hline Assertions & $\begin{array}{l}\text { Mean } \\
\text { value }\end{array}$ & $\begin{array}{l}\text { Standard } \\
\text { deviation }\end{array}$ \\
\hline $\begin{array}{l}\text { Decentralization and similar changes in organizational structure } \\
\text { (elimination of a department, establishing a new department, } \\
\text { merging segments, or departments). }\end{array}$ & 2.42 & 1.17 \\
\hline $\begin{array}{l}\text { Changes in the organization of the city or municipality } \\
\text { administration (changing the name of an administrative } \\
\text { department, or service, appointing new department managers, } \\
\text { increasing the number of departments). }\end{array}$ & 2.58 & 1.31 \\
\hline Establishing project teams when necessary. & 2.83 & 1.29 \\
\hline Delegation of decision-making authority. & 2.73 & 1.18 \\
\hline $\begin{array}{l}\text { A new system for measuring and evaluating employee performance } \\
\text { has been implemented. }\end{array}$ & 2.28 & 1.11 \\
\hline $\begin{array}{l}\text { A new system for measuring and evaluating management } \\
\text { performance has been implemented. }\end{array}$ & 2.00 & 1.04 \\
\hline A new employee reward system has been implemented. & 2.10 & 1.26 \\
\hline A new management reward system has been implemented. & 1.89 & 1.12 \\
\hline Criteria for management progress have been established. & 1.87 & 1.04 \\
\hline Criteria for employee progress have been established. & 2.06 & 1.08 \\
\hline $\begin{array}{l}\text { A job rotation technique has been practiced to rotate employee } \\
\text { assigned jobs throughout their employment aimed at employee } \\
\text { development and progress. }\end{array}$ & 1.93 & 1.13 \\
\hline An ISO quality management system has been implemented. & 1.72 & 1.12 \\
\hline A project management system has been implemented. & 2.56 & 1.20 \\
\hline $\begin{array}{l}\text { Your unit of local self-government consults and shares experience } \\
\text { with other local self-government units both in the country and } \\
\text { abroad to establish best practices in solving problems on a regular } \\
\text { basis. }\end{array}$ & 2.94 & 1.19 \\
\hline $\begin{array}{l}\text { An employee training and development system has been } \\
\text { implemented. }\end{array}$ & 2.45 & 1.19 \\
\hline
\end{tabular}

The surveyed local self-governmentunits identified the following management innovations that have contributed to high levels of implementation: 'Regularly consulting and sharing experience with other local self-government units both in the country and abroad to establish best practices in solving problems' (2.94), 'Establishing project teams when necessary' (2.83) and 'Delegation of decision-making authority' (2.73). Management innovations that have contributed to the lowest level of implementation were identified as follows: 'ISO quality management system implementation' (1.72), 'Establishing criteria for management progress' (1.87) and 'Management reward system implementation' (1.89). The extracted factor attained a specific value of $6.927(\mathrm{KMO}=0.839$, Bartlett $=603.329, \mathrm{p}<0.001)$ and the total explained variance contribution rate has reached $46.18 \%$. Cronbach's alpha estimate of reliability showed a coefficient of 0.91 . It can be concluded that the reliability of this scale is very good. 


\subsubsection{Effectiveness of Local Self-Government}

The effectiveness of local self-government refers to how a process of innovation implementation can produce desired effects, or, in other words, how the purpose of innovation is achieved. The paper examines effectiveness of local self-government in three measures:

1. Realized Budget to Employee Expenses Ratio. Data refer to the year 2013. Due to the high complexity of measuring public administration outputs, in this case local self-government, which is characterized by heterogenous services and activities, making selection of adequate comparative outputs referring to different cities and municipalities challenging, monetary value of realized budget was chosen as output measure. Budget means realized revenues respectively expenses divided by programs, activities or projects. Budget was therefore chosen as a comparative output measure to indicate variability of output among local self-government units. This is also in accordance with the OECD Guidelines considering the high complexity in output measurement in the service sectors (State of the NSW Public Sector Report (2012);

2. EU Funds Absorption Rate. Absorption rate of the EU funds indicates planning and managing ability aimed at achieving goals. In their work on cost efficiency of local self-government in Poland, Karbownik and Kula (2009) argued that the EU funds absorption rate could be viewed as a significant factor of efficiency. It can be concluded that the human factor is a key variable in explaining the absorption of EU funds and, consequently, it is implied that the implementation of management innovations, which is also determined by human factors, can have a positive impact on the absorption of EU funds. EU funds absorption rates obtained from available financial statements of local self-government units have been described as categorical variables, where 5 means that a local self-government unit absorbed EU funds in 2013 and 2012, 3 indicates that a local self-government unit absorbed EU funds in 2013 or in 2012, whereas 1 reveals that a local self-government unit did not absorb any EU funds neither in 2013 nor in 2012;

3. User Satisfaction on Local Self-Government Services. Or, satisfaction of entrepreneurs with services provided by local self-government. Entrepreneurship development is an important part of local selfgovernment strategies today. Entrepreneurs are thus an essential part of the business and it is important to respond adequately to their requirements. Based on previous evidence on user satisfaction, total satisfaction of entrepreneurs with local self-government services was measured by the following assertion (Danaher, Mattsson, 1994, Yukseland, Rimmington, 1998, Leisen, Vance, 2001, Theodorakis et al., 2001): Overall, how satisfied are you with the provision of services by your local self-government? The entrepreneurs evaluated their own 
satisfaction by the Likert scale from 1 - Not at all satisfied to 5 - Very satisfied.

Since the effectiveness of local self-government has been expressed in three measures, one of which is numerical (Realized Budget to Employee Expenses Ratio) and the other two are categorical type, the average of all three measures was calculated for the sake of data consistency, and then divided into five categories: 1-low effectiveness, 2-acceptable effectiveness, 3-good effectiveness, 4-very good effectiveness, 5-high effectiveness), and as a result an ordinal or structured variable was obtained.

\subsection{Analysis and Results}

Below are the results of hypothesis testing procedures:

H1: Financial Resources have a positive impact on an organisation's climate for implementation of management innovations.

H2: Top Management Support has a positive impact on an organisation's climate for implementation of management innovations.

H3: Absorptive Capacity has a positive impact on an organisation's climate for implementation of management innovations.

Table 6 shows the results of regression analysis with implementation climate as a dependent variable. In a hierarchical model, independent variables are entered cumulatively according to a specific, pre-determined hierarchy. Accordingly, three models or steps have been specified. Model 1 includes only the control variable, whereas Model 2 includes variables relating to financial resources and top management support. Model 3 refers to absorptive capacity. Absorptive capacity as a variable constitutes a separate step because it has been assumed that variables relating to financial resources and top management support are in a causal relationship with absorptive capacity. Likewise, the model created by Klein et al. (2001) described a causal relationship between variables relating to financial resources and top management support and the variables relating to implementation policy and practice. In our case, absorptive capacity covers variables relating to implementation policy and practice. 
Table 6. Results of regression analysis: Effects of financial resources, top management support and absorptive capacity on implementation climate

\begin{tabular}{|c|c|c|c|}
\hline \multirow[b]{2}{*}{ Predictors } & \multicolumn{3}{|c|}{ Implementation climate } \\
\hline & $\begin{array}{l}\text { Model } 1 \\
\text { Std. } \beta\end{array}$ & $\begin{array}{l}\text { Model } 2 \\
\text { Std. } \beta\end{array}$ & $\begin{array}{l}\text { Model } 3 \\
\text { Std. } \beta\end{array}$ \\
\hline $\begin{array}{l}\text { Step 1: Control variable } \\
\text { Size of local self-government unit }\end{array}$ & -0.035 & 0.002 & 0.075 \\
\hline $\begin{array}{l}\text { Step 2: Predictors } \\
\text { Financial resources } \\
\text { Top management support }\end{array}$ & & $\begin{array}{l}0.121 \\
0.828^{*}\end{array}$ & $\begin{array}{l}-0.032 \\
0.442^{*}\end{array}$ \\
\hline $\begin{array}{l}\text { Step 3: Predictor } \\
\text { Absorptive capacity }\end{array}$ & & & $0.489^{*}$ \\
\hline $\begin{array}{l}R^{2} \\
\Delta R^{2} \\
F \\
\Delta F\end{array}$ & $\begin{array}{l}0.001 \\
0.001 \\
0.065 \\
0.065\end{array}$ & $\begin{array}{c}0.67 \\
0.67 \\
35.25^{*} \\
52.79\end{array}$ & $\begin{array}{c}0.76 \\
0.09 \\
39.85^{*} \\
18.36\end{array}$ \\
\hline
\end{tabular}

$* p<0.001$

The results of the analysis show that the control variable of the size of local self-government unit does not make a significant contribution to the model. Newly introduced variables relating to financial resources and top management support accounted for an additional $67 \%$ of the variance of the implementation climate variable resulting in a significant $R^{2}$ change $(F=35.25$, $p<0.001)$. However, financial resources do not seem to have a significant impact on implementation climate, while top management support appears to have a significant positive impact $(\beta=0.828, p<0.001)$ on implementation climate. Hypothesis $\mathrm{H} 1$ has not been confirmed. On the other hand, Hypothesis $\mathrm{H} 2$ implying that top management support has a positive impact on implementation climate has been proven. Newly introduced variables relating to absorptive capacity accounted for an additional $9 \%$ of the variance, which means that this variable has made a significant contribution to the model $(F=39.85, p<0.001)$.

Below are the results of hypothesis testing procedures:

H4: Implementation climate has a positive impact on management innovation implementation.

H5: Innovation-values fit has a moderating effect on the relationship between implementation climate and management innovation implementation.

Table 7 shows the results of regression analysis with management innovation implementation as a dependent variable. Four models or steps have been defined. Model 1 includes only the control variable, whereas Model 2 introduced a predictor variable of implementation climate. Model 3 involves a moderator variable of innovation-values fit, whereas Model 4 indicates interaction effect of the two variables. 
Table 7. Results of regression analysis: Effects of implementation climate on management innovation implementation and a moderator impact of innovation-values fit

\begin{tabular}{|c|c|c|c|c|}
\hline \multirow{2}{*}{ Predictors } & \multicolumn{4}{|c|}{$\begin{array}{c}\text { Management innovation } \\
\text { implementation }\end{array}$} \\
\hline & $\begin{array}{l}\text { Model } 1 \\
\text { Std. } \beta\end{array}$ & $\begin{array}{l}\text { Model } 2 \\
\text { Std. } \beta\end{array}$ & $\begin{array}{l}\text { Model } 3 \\
\text { Std. } \beta\end{array}$ & $\begin{array}{l}\text { Model } 4 \\
\text { Std. } \beta\end{array}$ \\
\hline $\begin{array}{l}\text { Step 1: Control variable } \\
\text { Size of local self-government unit }\end{array}$ & 0.071 & 0.101 & 0.102 & 0.095 \\
\hline $\begin{array}{l}\text { Step 2: Predictor } \\
\text { Implementation climate }\end{array}$ & & $0.855^{* *}$ & $0.861^{* *}$ & $0.828^{* *}$ \\
\hline $\begin{array}{l}\text { Step 3: Moderator variable } \\
\text { Innovation-values fit }\end{array}$ & & & -0.026 & 0.071 \\
\hline $\begin{array}{l}\text { Step 4: Interaction effect } \\
\text { Implementation climate * Innovation-values } \\
\text { fit }\end{array}$ & & & & $0.191^{*}$ \\
\hline $\begin{array}{l}\mathrm{R}^{2} \\
\Delta \mathrm{R}^{2} \\
\mathrm{~F} \\
\Delta \mathrm{F}\end{array}$ & $\begin{array}{l}0.005 \\
0.005 \\
0.228 \\
0.228\end{array}$ & $\begin{array}{l}0.735 \\
0.730 \\
60.985^{* *} \\
121.133\end{array}$ & $\begin{array}{l}0.736 \\
0.001 \\
39.860^{* \star} \\
0.101\end{array}$ & $\begin{array}{l}0.763 \\
0.028 \\
33.849^{* *} \\
4.918\end{array}$ \\
\hline
\end{tabular}

* $p<0.05, * * p<0.001$

The control variable (size of local self-government unit) does not make a significant contribution to explaining the variance of the variable relating to management innovation implementation. Hypothesis H4 implying that implementation climate has a positive impact on management innovation implementation has been confirmed $(\beta=0.855, p<0.001)$. Besides this direct impact, there is also the moderating effect, which means that the variable of innovation-values fit (alignment between values created through management innovations and the organisation's values) moderates or, in other words enhances or weakens positive impact of implementation climate on management innovation implementation ( $\mathrm{H} 5)$. The moderating effect is tested by constructing a special new variable of the product of predictor and moderator, which is the carrier of eventual interaction, and is included in the regression equation as the last predictor variable. A significant change in the percentage of contribution to the explanation of the variance of the criterion after the inclusion of the last variable reveals the significance of the interaction. This means that the examined variable tends to moderate the relationship between the predictor and the criterion. The results suggest that the newly introduced variable of interaction accounted for an additional $2.8 \%$ of the variance, which does not make a notable change, but the effect is statistically significant $(\beta=0.191, p<0.05, F=33.85, p<0.001)$. It can be concluded that this relationship is modestly moderating and that in this sense the impact of implementation climate on management innovation implementation will increase, which proves Hypothesis H5.

Below are the results of hypothesis testing procedures: 
H6: Management innovation implementation has a positive effect on local self-government performance.

Tables 8 and 9 show the results of the global test with the hypothesis that all coefficients in the model are equal to 0 , but this assumption is rejected ( $p<0.0001)$, which means that at least one independent variable in the model tends to affect and describe the variable of effectiveness of local selfgovernment.

Table 8. Results of the global test

\begin{tabular}{|l|l|l|}
\hline \multicolumn{2}{|c|}{ Model Fit Statistics } \\
\hline Criterion & $\begin{array}{l}\text { Intercept } \\
\text { Only }\end{array}$ & $\begin{array}{l}\text { Intercept and } \\
\text { Covariates }\end{array}$ \\
\hline AIC & 201.316 & 175.967 \\
\hline SC & 210.367 & 189.543 \\
\hline-2 Log L & 193.316 & 163.967 \\
\hline
\end{tabular}

Table 9. Results of the global test

\begin{tabular}{|l|l|l|l|}
\hline \multicolumn{5}{|c|}{ Testing Global Null Hypothesis: BETA=0 } \\
\hline Test & Chi-Square & DF & Pr $>$ ChiSq \\
\hline Likelihood Ratio & 29.3498 & 2 & $<.0001$ \\
\hline Score & 21.0199 & 2 & $<.0001$ \\
\hline Wald & 24.8153 & 2 & $<.0001$ \\
\hline
\end{tabular}

This is further confirmed by maximum likelihood estimation, the results of which are given in the table below (Table 10).

Table 10. Analysis of Maximum Likelihood Estimates

\begin{tabular}{|l|l|l|l|l|l|l|}
\hline \multicolumn{7}{|c|}{ Analysis of Maximum Likelihood Estimates } \\
\hline Parameter & & DF & Estimate & $\begin{array}{l}\text { Standard } \\
\text { Error }\end{array}$ & $\begin{array}{l}\text { Wald } \\
\text { Chi-Square }\end{array}$ & Pr > ChiSq \\
\hline Intercept & 5 & 1 & -6.7983 & 1.0777 & 39.792 & $<.0001$ \\
\hline Intercept & 4 & 1 & -4.7917 & 0.8228 & 33.9141 & $<.0001$ \\
\hline Intercept & 3 & 1 & -2.588 & 0.6625 & 15.259 & $<.0001$ \\
\hline Intercept & 2 & 1 & 0.4117 & 0.7595 & 0.2938 & 0.5878 \\
\hline $\begin{array}{l}\text { Management } \\
\text { innovation } \\
\text { implementation }\end{array}$ & 1 & 1.5079 & 0.3035 & 24.6866 & $<.0001$ \\
\hline $\begin{array}{l}\text { Size of local self- } \\
\text { government } \\
\text { unit }\end{array}$ & 1 & -0.00217 & 0.00331 & 0.4309 & 0.5115 \\
\hline
\end{tabular}

Table 10 indicates that the management innovation implementation coefficient makes a significant contribution to the model $(p<0.0001)$, 
whereas the size of local self-government unit as the control variable does not produce a statistically significant effect $(p=0.5115)$ on the effectiveness of local self-government. Table 11 describes the impact of management innovation implementation on effectiveness.

Table 11. Odds Ratio Estimates

\begin{tabular}{|l|l|l|l|}
\hline \multicolumn{4}{|c|}{ Odds Ratio Estimates } \\
\hline Effect & $\begin{array}{l}\text { Point } \\
\text { Estimate }\end{array}$ & \multicolumn{2}{|l|}{$\begin{array}{l}\text { 95\% Wald } \\
\text { Confidence Limits }\end{array}$} \\
\hline $\begin{array}{l}\text { Management innovation } \\
\text { implementation }\end{array}$ & 4.552 & 2.504 & 8.273 \\
\hline Size of local self-government unit & 0.998 & 0.991 & 1.004 \\
\hline
\end{tabular}

The odds ratio for the management innovation implementation variable is 4.552. It can be said that with every increase in the management innovation implementation variable for a single rating, the odds ratio that the effectiveness of local self-government will reach a higher category increases by 4.552 times. So, the higher the level of implementation of management innovations (better rating), the greater the effectiveness.

\section{Discussion}

The hypotheses proposed in the paper have been in most part proven, which makes a strong point of the importance and need for a more intensive research into these types of innovation. Hypothesis $\mathrm{H} 1$, which implied that financial resources could have a positive impact on implementation climate, was the only one that has not been confirmed. In other words, financial resources as a variable proved to be insignificant. In a similar way, Sawang (2008) in its research on implementing several types of innovation simultaneously also confirms that the financial resource adequacy variable tends to have an insignificant influence on implementation policies and practices, assumed by the authors of this work to be incorporated in the absorptive capacity variable. When the hypothesis was formed, it was assumed that the impact of financial resources on implementation climate would be less pronounced - as proven. The above suggests that financial resources do not make a significant contribution to implementing a successful management innovation process. The results can be interpreted as being consistent with existing theoretical constructs in the field of management innovations, defined as non-technological types of innovation, which do not require significant financial resources in development and implementation. This is particularly true in a public sector environment, which involve organizations that tend to implement innovations, which are mostly incremental in nature. In other words, this survey does not involve radical innovations (where radical innovation means significant financial 
resources), but focuses on innovations that are produced to help upgrade the existing practices and methods.

Likewise, testing the hypothesis of positive impact of top management support ( $\mathrm{H} 2$ ) and absorptive capacity (H3) on an organisation's climate for implementation of management innovations, emphasised the significance of intangible organizational factors, such as cooperation and exchange of knowledge and experience among local self-government units and other stakeholders in the environment to create positive perception of the importance of introducing new management methods and concepts. This suggests that top management support and absorptive capacity are very important measures in reaching a higher level of implementation of management innovations. The results have revealed the importance of collaboration and knowledge sharing in organizations that tend to implement management innovations. Levinson and Asahi's study (1995) also supports the assertion that cooperation and exchange of knowledge and experience among local self-government units and inter-organizational learning activity have become a vital factor in contributing to improve knowledge acquisition or absorptive capacity. In his work, Černe (2013) also confirms the assertion where he assumed and proved that knowledge exchange can have a positive influence in anticipation of future management innovations. The described activities also proved to be successful in Croatian local self-government practice in a case study conducted by Grčić Fabić and Mičetić Fabić (2013), where the cities selected based on the degree of successful innovation implementation were those who had developed processes of partnership, networking and cooperation and exchange of experience with other units of local self-government. This supports the idea that management innovations are developed or adopted primarily through interaction with the environment (Birkinshaw, Mol, 2006). Factors of top management support and absorptive capacity as the ability to acquire, assimilate, and apply knowledge are much more important than disposing of great amount of financial resources for successful implementation of management innovations.

Our results have revealed that implementation climate can have a positive impact on management innovation implementation. Evaluation of results derived from $\mathrm{H} 4$ and $\mathrm{H} 5$ test certified the assumption that implementing a successful management innovation process appears to be strongly influenced by organizational members' perceptions of the importance of implementing innovation in the organization $(\mathrm{H} 4)$ and the alignment between values created through management innovations and their own values, or vision of their own development within the organization (H5). Accordingly, it can be concluded that social spheres of the organisation are very important for management innovation implementation, as proposed in existing management innovation constructs. Acting through those segments can influence to implementing a successful management innovation process. As previous studies have not investigated the direct correlation between implementation climate and 
management innovations, evidences to support the assertion that there is a positive correlation between the two variables can be found in studies on implementation of process innovation (Holahan et al., 2004, Klein et al., 2001) and innovation that would seem to be a collective construct that involves broader range of types of innovation, including management innovation (Sawang, 2008).

Evaluation of results derived from $\mathrm{H} 6$ test asserted a positive impact of implementing new management concepts and methods on improving the effectiveness of local self-government. Researches undertaken in the private sector also confirmed the assertion (Černe, 2013, Volberda et al., 2013, Camisón, Villar-López, 2012, Walker et al., 2011, Gunday et al., 2011, Sapprasert, 2008, Yeh-Yun Lin, Yi-Ching Chen, 2007, Gera, Gu, 2004, Linderman et al., 2004). Within the public sector, the research carried out by Walker et al. (2011) should be emphasized. They were able to prove that there are indirect, positive effects of management innovation on organizational performance.

By implementing a successful management innovation process, units of local self-government will be able to achieve higher user satisfaction with the services they provide, higher EU funds absorption rates and higher budget value per monetary unit of investment in employees. Likewise, it is important to point out that management innovations break into social spheres of the organization. This means that intangible organizational factors appear to be more important in the implementation of management innovations than those having tangible outcomes such as financial resources.

\section{Conclusion}

The proposed hypotheses have been successfully confirmed for the most part by testing the proposed conceptual model of factors contributing to the implementation of management innovations, emphasizing the importance and need for more intensive research of this type of innovation. The hypothesis $\mathrm{H} 1$ was the only one rejected, where the financial resource adequacy variable proved insignificant. Also, the paper enabled to consider those factors that contribute to the successful implementation of management innovations, ultimately leading to more effective local self-government units. The empirical research on management innovation has been extended to include the public sector, considering that only few studies have, to date, focused on this type of innovation in the public sector.

The challenge of implementing management innovations is more relevant than ever. Developing this type of innovation is becoming increasingly important particularly in the public sector which is facing intensifying pressures for increased effectiveness, or cost rationalization and high quality public services. Functional decentralization or the transfer of authority and responsibility from the centre to lower levels of administration tends to intensify the pressures even more, and thus the need for implementing 
management innovations. Local government managers need to be aware that implementing a successful management innovation process does not require investing great amount of financial resources, unlike process innovations, for example. There is no need for special expertise and infrastructure (as is the case with technological innovations, which often requires the establishment of a R\&D department, expert knowledge and significant financial resources). Factors of top management support and absorptive capacity as the ability to acquire, assimilate, and apply knowledge are much more important than disposing of great amount of financial resources for successful implementation of management innovations.

In accordance with the foregoing, public sector managers, in addition to providing support for implementation of new methods and conceptions of governance by adopting effective measures for rewarding new approaches to work organization, problem solving, and generally a proactive approach to proposing new projects and methods - must foster cooperation and sharing experience with other units of local self-government, work in partnership and create networks to improve the effectiveness of the local self-government unit they manage.

This study has some limitations which have to be pointed out, and can be used as a guideline for future research. Ideally, the study should be extended to include other countries as well to cover distinct types of environment, thus including those variables that consider the context within which the management innovations are being implemented. Also, as a guideline for future research, it is desirable to test the model on private sector organizations as well, thus enabling comparisons between private and public sector to identify similarities and differences.

Professor Zdravko Zekić was born in Zadar on December 1, 1960. He is a citizen of the Republic of Croatia, and holds Croatian nationality. After finishing high school in Rijeka in 1979, he enrolled in the Faculty of Economics in Rijeka. He received his university degree in 1984 after successfully defending his Master's Thesis II entitled »Rijeka Oil Refinery INA Ltd. - Calculation and Allocation of Revenue and Income" under the mentorship of Professor Zvonimir Etinger. As a Rijeka Oil Refinery schoolarship holder, he was employed in their Accounting and Finance Department as Planning Analyst. In 1987, he took up the manager's role at the municipality of Buzet, where he served as Head of Department of Economics. During the period from 1990 to 1995, he worked for the Istra Genetic Centre at his position as Director of Financial Engineering for implementation of international investment projects based on the Memorandum of Understanding on the cooperation between the Republic of Croatia and the Republic of Italy. After the realization of the investment project, in 1995 he founded his own company, currently registered as Conefing Group 
for strategic management and investment consulting, which has three affiliated companies and it now employs more than 70 higher education employees.

Mirjana Grčić Fabić, PhD in Economics, has been employed at the Faculty of Economics, University of Rijeka. Her teaching and research interests spans multiple areas of research; Public Management, Management, Entrepreneurial Economics, Innovation and Organization Design. She is the author of research and professional articles in the field of public management and innovation management. As part of her research activity, she participates in international research conferences. She is a member and actively involved in research projects Development of Management in Function of EU Integration in the EU, funded by the University of Rijeka, and Model of Measurement of the Efficiency of Public Health Services, funded by the Croatian Science Foundation.

Luka Samaržija was born in Rijeka on September 20, 1982. Shortly after graduating from undergraduate studies in International Economics at the Faculty of Economics in Rijeka in 2006, he was employed at Liccos Ltd., where he took up his role of Manager of Service Department. During the period from 2006 to 2009, he pursued his postgraduate degree: "Doing business in the EU" as a specialty. In 2009, he successfully defended his thesis on "Croatian Wood Competitiveness Cluster Strategy for penetrating the EU market". In January 2010, he was employed at the Faculty of Economics in Rijeka. He is currently Assistant Professor in Management, Project Management and Logistics Management. 


\section{References:}

Birkinshaw, J., \& Mol, M. (2006). How Management Innovation Happens. MIT Sloan Management review (4), 81-88.

Birkinshaw, J., Hamel, G., \& Mol, M.J. (2008). Management innovation. Academy of Management Review (4), 825-845.

Braunscheidel, M. J., Hamister, J. W., Suresh, N. C., \& Star, H. (2011). An institutional theory perspective on Six Sigma adoption. International Journal of Operations \& Production Management.

Bryson, A., Dale-Olsen, H., \& Barth, E. (2009). How Does Innovation Affect Worker Well-being?, Centre for Economic Performance, CEP Discussion Paper No. 953.

Camisón, C., \& Villar-López, A. (2012). Organizational innovation as an enabler of technological innovation capabilities and firm performance. Journal of Business Research (1), 2891-2902.

Choi, S., \& Chang, J. (2009). Redesigning plan of career development program for profession of public official. Korea administration research institute, Seoul

Cohen, W.M., \& Levinthal, D.A. (1989). Innovation and learning: The two faces of R\&D. Economic Journal (99), 569-596.

Černe, M. (2013). A Multilevel Approach in examining non-technological innovation. Ph. D. Ljubljana: University of Ljubljana, Faculty of Economics.

Damanpour, F., \& Schneider, M. (2006). Phases of the Adoption of Innovation in Organizations: Effects of Environment, Organization and Top Managers. British Journal of Management 17(3), 215-236.

Danaher, P., \& Mattsson, J. (1994). Customer Satisfaction in the Service Delivery Process. European Journal of Marketing 28(5), 516.

Gebauer, H. (2011). Exploring the contribution of management innovation to the evolution of dynamic capabilities. Industrial Marketing Management (40), $1238-1250$.

Gebauer, H., Gustafsson, A., \& Witell, L. (2011). Competitive advantage through service differentiation by manufacturing companies. Journal of Business Research (64), 1270-1280.

Gera S., \& Gu, W. (2004). The Effect of Organizational Innovation and Information Technology on Firm Performance. International Performance Monitor (9), 37-51.

Grčić Fabić, M., Zekić, Z., \& Samaržija, L. (2016). Implementation of management innovation - a precondition for the development of local government effectiveness: evidence from Croatia. Administration and Public Management Review (27), 7-29.

Grčić Fabić, M., \& Mičetić Fabić, M. (2013). Management and innovation capabilities and local government performance-case of local government in Croatia. XX. Dnevi slovenske uprave, Conference Proceedings. Ljubljana: Fakulteta za upravo.

Gunday, G., Ulusoy, G., Kilic, K., \& Alpkan, L. (2011). Effects of Innovation Types on Firm Performance. International Journal of Production Economics (2), 662-676.

Hamel, G., \& First (2011). Let's Fire All the Managers. Harvard Business Review (12), 48-60. 
Helfrich, C., Weiner, B., McKinney, M., \& Minasian, L. (2007). Determinants of Implementation Effectiveness: Adapting a Framework for Complex Innovations. Medical Care Research and Review (64)3.

Holahan, P.J., Aronson, Z.H., Jurkat, M.P., \& Schoorman, F.D. (2004). Implementing computer technology: a multi-organizational test of Klein and Sorra's model. J. Eng. Technol. Management (21), 31-50.

Holbrook, A.L., \& Krosnick, J.A. (2010). Social desirability bias in voter turnout reports, Tests using the item count technique. Public Opinion Quarterly (74) 1, 37-67.

Jensen, T. B., \& Aanestad, M. (2007). How Healthcare Professionals »Make Sense« of an Electronic Patient Record Adoption. Information Systems Management 24(1), 29.

Jones, N.B., \& Kochtanek, T.R. (2004). Success factors in the implementation of a collaborative technology and resulting productivity improvements in a small business: an exploratory study. Journal of Organizational and End User Computing (16)1, 1-20.

Karbownik, B., \& Kula, G. (2009). Efficiency of public sector at the level of local governments in Poland. http://www.seminar.wne.uw.edu.pl/uploads/Main/ Karbownik_Kula.pdf.

Kennedy, A., Kelleher, C., \& Quigley, M. (2006). CRM Best Practice: Getting it Right First Time at ESBI. Irish Management Journal, 55-273.

Klein, K. J., \& Sorra, J. S. (1996). The challenge of innovation implementation. Academy of Management Review (21)4, 1055-1080.

Klein, K. J., Conn, A. B., \& Sorra, J. S. (2001). Implementing computerized technology: An organizational analysis. Journal of Applied Psychology (86)5, 811-824.

Koch, A., \& Strotmann, H. (2008). Absorptive capacity and innovation in the knowledge intensive business service sector. Economics of Innovation and New Technology (17)6, 511-531.

Kossek, E. E. (1987). Human resources management innovation. Human Resource Management (26), 71-91.

Kostopoulos, K., Papalexandris, A., Papachroni, M., \& loannou, G. (2011). Absorptive capacity, innovation, and financial performance. Journal of Business Research (64)12, 1335-1343.

Leisen, B., \& Vance, C. (2001). Cross-National Assessment of Service Quality in the Telecommunication Industry: Evidence from the USA and Germany. Managing Service Quality (11)5, 307-317.

Levinson, N., \& Asahi, M. (1995). Cross-national alliances and interorganizational learning. Organizational Dynamics (24)2, 50-63.

Linderman, K., R. G., Schroeder, S., Zaheer, C., Liedtke A. S., \& Choo (2004). Integrating quality management practices with knowledge creation processes. Journal of Operations Management (22), 589-607.

Letaifa, S. B., \& Perrien, J. (2007). The Impact of E-CRM on organisational and Individual behavior: the Effect of the remuneration and reward system. International Journal of Ebusiness Research (3)2, 13-23.

Lorsuwannarat, T. (2013). Innovation discontinuation in public organizations: From the institutional and ecological perspectives. Thai Journal of Public Administration (11), 1. 
Mehrtens, J., Cragg, P. B., \& Mills, A. M. (2001). A model of Internet adoption by SMEs. Information \& Management 39(3), 165-176.

Mele, C., \& Colurcio, M. (2006). The evolving path of TQM: towards business excellence and stakeholder value. International Journal of Quality and Reliability Management (5), 464-489.

Mol, M.J., \& Birkinshaw, J. (2009). The sources of management innovation: When firms introduce new management practices. Journal of Business Research (12), 1269-1280.

Noblet, A., Rodwell, J., \& McWilliams, J. (2006). Organizational change in the public sector: Augmenting the demand control model to predict employee outcomes under New Public Management, Work \& Stress. An International Journal of Work, Health \& Organisations (20)4.

Orlikowski, W. J. (1993). CASE tools as organizational change: Investigating incremental and radical changes in system development. MIS Quarterly (17)3, 309-340.

Pullig, C., Maxham, J.G., \& Hair, J.F. (2002). Salesforce automation systems-an exploratory examination of organizational factors associated with effective implementation and sales force productivity. J. Bus. Res. (55), 401-415.

Purvis, R.L., Sambamurthy, V., \& Zmud, R.W. (2001). The assimilation of knowledge platforms in organizations: An empirical investigation. Organization Science (12)2, 117-135.

Rodwell, J.J., Noblet, A.J., \& Allisey, A.F. (2009). Improving employee outcomes in the public sector: The beneficial effects of social support at work and job control. Personnel Review (40)3, 2011.

Sapprasert, K. (2008). Acknowledging Organizational Innovation, in Ostreng, W. (ed.) Interdisciplinary Communications 2007/2008. Norway: Centre for Advanced Study at the Norwegian Academy of Science and Letters, Forthcoming.

Sawang, S. (2008). Innovation implementation effectiveness: a multiorganizational test of Klein Conn and Sorra's model. Ph. D. Queensland University of Technology.

State of the NSW Public Sector Report 2012, http://www.psc.nsw.gov.au/ reports---data/state-of-the-sector/previous-editions/state-of-the-sectorreport-2012.

Stock, G.N., Greis, N.P., \& Fischer, W.A. (2001). Absorptive capacity and new product development. Journal of High Technology Management Research (12), 77-91.

Suchan (2001). The effect of interpretative schemes on videoteleducation's conception, implementation, and use. Journal of Business and Technical Communication 15(2), 133.

Theodorakis, N., Kambitsis, C., Laios, A., \& Koustelios, A. (2001). Relationship between measures of service quality and satisfaction of spectators in professional sports. Managing Service Quality (11)6, 431-438.

Tidd, J. (2001). Innovation management in context: Environment, organization and performance. International Journal of Management Reviews (3)3, 169183.

Tsai, W. (2001). Knowledge Transfer in Intraorganizational Networks: Effects of Network Position and Absorptive Capacity on Business Unit Innovation and Performance.The Academy of Management Journal (44), 996-1004. 
Vaccaro, I.G., Jansen, J.J.P., Van Den Bosch, F.A.J., \& Volberda, H.W. (2012). Management Innovation and Leadership: The Moderating Role of Organizational Size. Journal of Management Studies (1), 28-51.

Vigoda-Gadot, E., \& Meiri, S. (2008). New public management values and personorganization fit: A socio-psychological approach and empirical examination among public sector personnel. Public Administration (86), 1.

Voet, J. (2013). The effectiveness and specificity of change management in a public organization, Transformational leadership and a bureaucratic organizational structure. European Management Journal (32), 373-382.

Volberda, H. W., Van Den Bosch, F. A. J., \& Heij, C. V. (2013). Management innovation: Management as fertile ground for innovation. European Management Review (10), 1-15.

Walker, R.M. (2006). Innovation type and diffusion: An empirical analysis of local government. Public Administration (84)2, 311-335.

Walker, R.M., Damanpour, F., \& Devece, A.C. (2011). Management Innovation and Organizational Performance: The Mediating Effect of Performance Management. Journal of Public Administration Research and Theory (21)2, 367-386.

Weiner, B., Lewis, M. \& Linnan, L. (2009). Using organizational theory to understand the determinants of effective implementation of worksite health promotion programs. Health Education Research (24)2, 292-230.

Weiner, B.J., Belden, C.M., Bergmire, D.M, \& Johnston, M. (2011). The meaning and measurement of implementation climate. Implementation Science (78)6, $1-12$.

Yeh-Yun Lin, C., \& Yi-Ching Chen, M. (2007). Does innovation lead to performance? An empirical study of SMEs in Taiwan. Management Research News (30)2, 115-132.

Yüksel, A. \& Rimmington, M. (1998). Customer-satisfaction measurement. Cornell Hotel and Restaurant Administration Quarterly (39), 60-70. 


\section{Dejavniki, ki vplivajo na uspešno izvajanje managerskih inovacij}

Pojem inovacij v upravljanju kot posebna vrsta netehnoloških inovacij je še vedno na začetku pojmovnega oblikovanja in potrditve. $V$ nasprotju s tehnološkimi inovacijami, ki zadevajo spremembe v tehnologiji, povezane z osnovno dejavnostjo organizacij, inovacije v upravljanju pomenijo preboj na socialna področja, poudarek pa je na ljudeh - vodjih. Inovacije v upravljanju lahko opredelimo kot postopek ustvarjanja in izvajanja novih praks, postopkov, struktur ali tehnik v upravljanju, ki lahko bistveno odstopajo od obstoječih praks in standardov. Obstoječe študije na področju inovacij v upravljanju večinoma ocenjujejo vpliv inovacij v upravljanju na organizacijske rezultate, ne upoštevajo pa tistih dejavnikov, ki spodbujajo oblikovanje in izvajanje teh inovacij. Ta dokument si zastavlja raziskati pojem inovacij v upravljanju v organizacijah javnega sektorja s poudarkom na opredeljevanju vpliva organizacijskih dejavnikov na uspešno izvajanje inovacij v upravljanju, zlasti v organizacijah javnega sektorja ali lokalnih samoupravnih enotah na Hrvaškem, kar bo omogočilo analizo inovacij v upravljanju tako z vidika samega postopka izvajanja kot tudi z vidika pričakovanih učinkov inovacij.

Predhodne študije so se večinoma osredotočale na vpliv inovacij v upravljanju na organizacijsko učinkovitost v zasebnem sektorju, medtem ko je le malo raziskav obravnavalo javni sektor. Zato je javni sektor zanimivo področje za raziskavo vpliva izvajanja inovacij v upravljanju. Poleg tega je bila raziskava prilagojena kontekstu lokalne samouprave zaradi posebnosti lokalne uprave kot najnižje ravnijavne uprave, karje v njeno korist ali, z drugimi besedami, njena temeljna naloga. To nakazuje na zmožnost lokalne samouprave, da zagotavlja lokalne javne dobrine v skladu z lokalnimi preferencami na bolj stroškovno učinkovit način kot višje ravni javne uprave. To vodi do bolj fleksibilnega in kreativnega pristopa do opravljanja javnih storitev, ki zahteva inovativne rešitve in strategije za ustrezno odzivanje na spremembe v lokalnem okolju v nasprotju s storitvami, ki jih opravljajo najvišje ravni javne uprave. Izvajanje novih upravljalnih metod in praks je bilo razumljeno kot prizadevanje za izboljšanje učinkovitosti in uspešnosti pri opravljanju javnih storitev.

Predlagane hipoteze so bile večinoma uspešno potrjene s testiranjem predlaganih pojmovnih modelov dejavnikov, ki prispevajo k uspešnemu izvajanju inovacij v upravljanju, s poudarkom na pomembnosti in potrebi po intenzivnejših raziskavah teh tipov inovacij. Pridobljeni rezultati potrjujejo pojmovne determinante izraza inovacij v upravljanju, kot se prikaže pod vplivom izbranih organizacijskih dejavnikov, ki prispevajo k uspešnemu 
izvajanju inovacij v upravljanju, in ki lahko pripelje do povečanja učinkovitosti lokalnih enot samoupravljanja. V skladu s tem so bile absorpcijske sposobnosti in podpora najvišjega vodstva skupaj s kombiniranimi učinki klime izvajanja in ustreznostjo inovacijskih vrednosti opredeljeni kot ključni dejavniki za doseganje uspešnega izvajanja inovacij v upravljanju. Po drugi strani pa ni bilo ugotovljeno, da bi bila dosegljivost obsežnih finančnih sredstev pomemben dejavnik za učinkovito izvajanje tega tipa inovacij. Z izvajanjem uspešnega postopka inovacij v upravljanju bodo lokalne enote samoupravljanja lahko dosegle večje zadovoljstvo uporabnikov s storitvami, ki jih nudijo, višjo stopnjo absorpcije evropskih sredstev in večjo proračunsko vrednost na denarno enoto naložb v zaposlene. Pri načrtovanju doseganja teh rezultatov je pomembno, da ne pozabimo, da inovacije v upravljanju pomenijo preboj na socialna področja organizacije. Z drugimi besedami so neopredmeteni organizacijski dejavniki pomembnejši za uspešno izvajanje inovacij v upravljanju kot opredmeteni dejavniki, kot je na primer ustreznost finančnih virov.

$\checkmark$ tej študiji se pokažejo tudi nekatere omejitve, ki jih je treba izpostaviti in ki jih lahko uporabimo kot smernice za prihodnje raziskave. Glavna omejitev je bil geografski obseg študije. $V$ idealnem primeru bi študijo razširili, da bi vključevala tudi druge države in pokrivala različne vrste okolja ter s tem vključevala tudi tiste spremenljivke, ki upoštevajo kontekst, znotraj katerega izvajamo inovacije v upravljanju. Prav tako bi bilo zaželeno, da bi študija vključevala tudi zasebni sektor ter s tem omogočila primerjavo med zasebnim in javnim sektorjem, s čimer bi lahko opredelili podobnosti in razlike med njima.

Ključne besede: managerske inovacije, netehnološke inovacije, izvajanje inovacij, lokalna samouprava, učinkovitost. 